\title{
曲り管ダクトの音響特性および流体音特性に関する研究
}

石原 国彦*1

\section{Study on Acoustic and Flow Noise Characteristics of Bending Duct}

\author{
Kunihiko ISHIHARA *1 \\ ${ }^{* 1}$ The University of Tokushima, Faculty of Engineering, \\ 2-1 Minami-Zyosanjima-Cho, Tokushima-City, Tokushima-Pref,770-8506
}

An air conditioning equipment is usually set to keep a rail vehicle comfortable. However its noise is annoying especially when the vehicle is stationary. The noise reduction is very important from the point of view of keeping the car interior space comfortable and is one of the differentiating techniques for the manufactures. This paper describes acoustic and flow noise characteristics of the bending duct. The experiments were carried out in various parameters such as the absorbing ability, bending numbers and flow velocities by use of the bending duct. As a result, it was clarified that the noise reduction effect due to the bending is proportional to the number of times of bending. Moreover the reduction of pressure losses by use of the guide and the airfoil is very effective to the noise reduction.

Key Words : Aerodynamic Acoustics, Measurement, Bending Duct, Noise, Railway, Air Conditioning, BEM

\section{1. 緒言}

鉄道車両では快適性を保つため空調装置か設置されているが, 空調騒音か問題となる場合も時折見られる.特 に停車時などでは空調騒音が耳障りになることはよく経験するところである．したがって空調騒音の低減化は快 適性確保の観点から重要であり，差別化技術の一つと位置付けられる .

空調装置はファンと開口部を有するダクトからなっており，音源としてはファン自身から発生する，いわゆる ファン音, 設置上やむをえず作られるダクトの曲がり部や拡大部において流れか渌離するときの流体音, 乥して 客室に直接風を吐き出す開口部流体音の3つが存在する . しかしながらどの音源か汥配的であるかは十分把握で きていないのか現状である .

騒音低減化では支配的な音源から対策するのか鉄則であることから，まず客室の騒音に及ぼす各種音源の寄与 度を把握することが研究の第一歩となる . 谷のためには光れ光れの音源について客室への騒音レべルを把握する 必要がある. 弚こで本研究では, これら 3つの騒音源のうち, ファン音を除いた剥離に起因する流体音と多クト 開口部からの流体音について乥れらの騒音特性を調べる .

ダクト内部で発生する騒音については渡辺らによる発生パワーレベルを求めたもの ${ }^{(1)}$, 板本 , 塩川によるグラ ス・ファイバ・ダクトの音響特性や気流による発生音を求めたもの ${ }^{(2) \sim(5)}$, 板本らによる内張りダクトでの気流お よび音響特性を調べたものなど ${ }^{(6)}$ がありデータ集としてもよく用いられている(7).しかしながら，空調ダクトの ようなダク卜敗壁に開口部を有するようなダクトに対しての音響特性や気流による発生音についての研究は少な $い^{(8),(9)}$.

乥こで本研究では開口部を有するダクトを空調ダクトに見立てて, (1) ダクト内発生騒音と開口部騒音の寄与 度の把握 , ( 2 ) 曲がり部, 急拡大部で発生する騒音アップ量の把握などを実験的に行い, 弚の後 (3) 対策案の

\footnotetext{
* 原稿受付 2010 年 8 月 27 日

*1 正員 , フェロー, 徳島大学大学院ソシオテクノサイエンス研究 ( ₹ 770-8506 徳島県徳島市南常三島町 2-1)

E-mail: ishihara@me.tokushima-u.ac.jp
} 


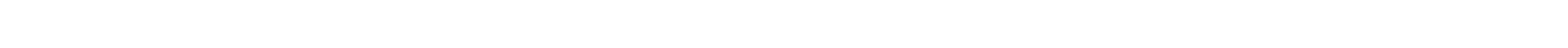
実験により音響特性 ${ }^{(8)}$ おび流体音特性 ${ }^{(9)}$ を明らかにしたので, 本報では開口無し曲りダクトについて (a) 音響 特性，(b) 曲りダクトの流れによる騒音の増加量，(c) 录樆倠方止デバイスの騒音低減効果に関する実験結果につ いて述べる。

\section{2. 音響特性に関する実験（気流無）}

\section{$2 \cdot 1$ 実験装置}

実験装置を図 1 に示す . また谷の写真を図 2 に示す . 写真では端部か閉となっているか実験は開放して行って いる.無響室に導かれた風洞吹出口 (200口断面) にダクト断面が $200 \mathrm{~mm} \times 200 \mathrm{~mm}$ の曲がりダクト (厚み $2.3 \mathrm{~mm}$ の鉄板にて製作) を取り付け，図に示した位置すなわち原点より $\mathrm{P} 1=0.6 \mathrm{~m}, \mathrm{P} 2=1.25 \mathrm{~m}, \mathrm{P} 3=1.85 \mathrm{~m}, \mathrm{P} 4=2.4 \mathrm{~m}$ の各位

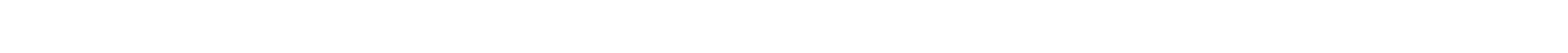
把握するため，一つの場合の実験は図に示す A 部より下流を取り外して行った . なお , 赤線で示した中心線長さ

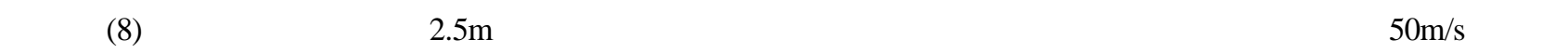
ける吹き出し口中心から $500 \mathrm{~mm}$ 位置での暗騒音レベルが $61 \mathrm{~dB}(\mathrm{~A})$, 乱れ度は $1 \%$ 以下, 吹き出し口における平均 速度の非一樣性は 1 \%以下である . また無風時の暗騒音レベルは $23 \mathrm{~dB}(\mathrm{~A})$ である.

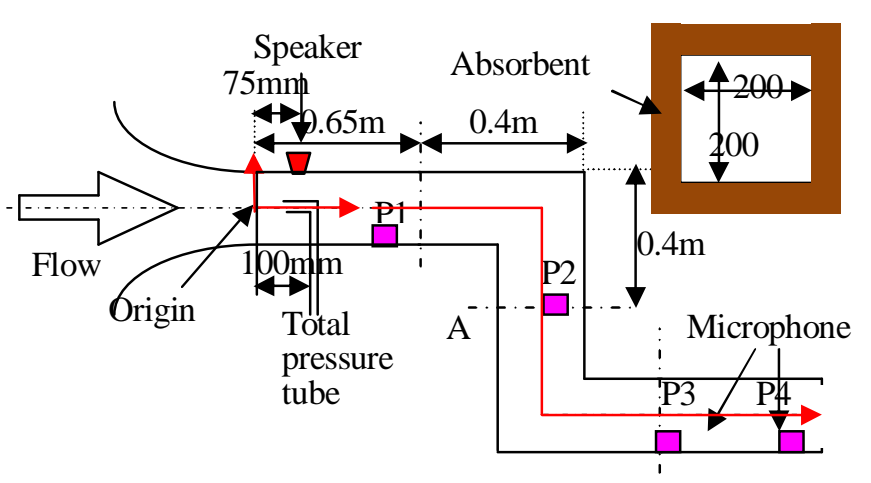

Fig.1 Test apparatus

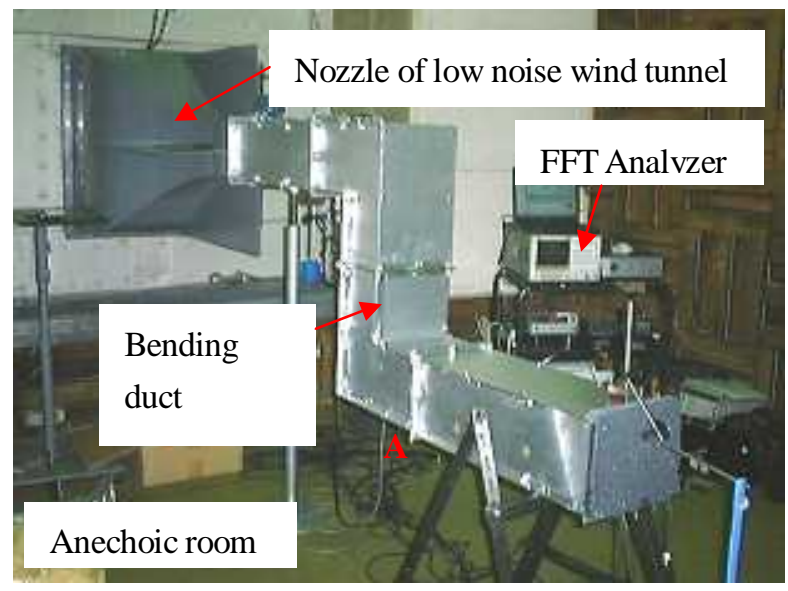

Fig.2 Photo of test apparatus

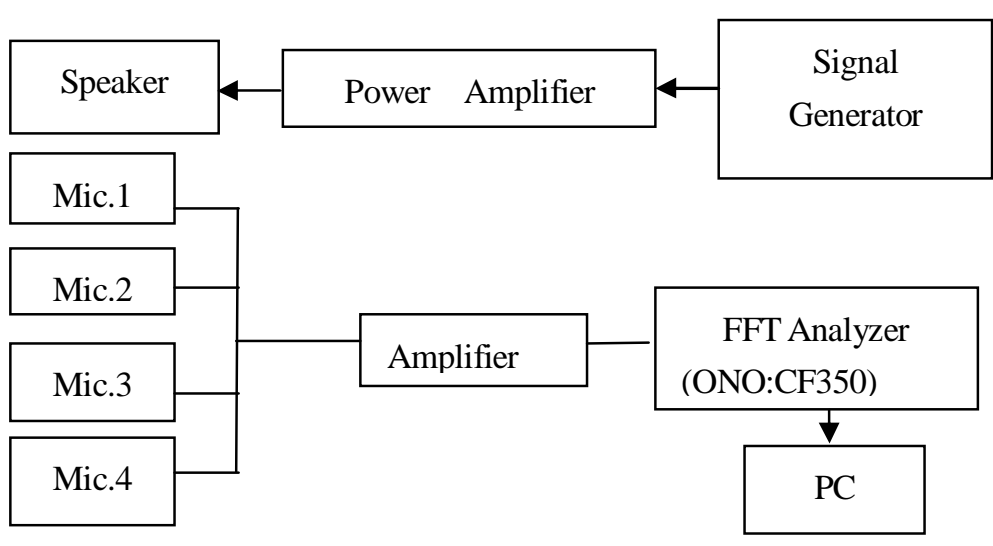

Fig.3 Measuring block diagram 


\section{$2 \cdot 2$ 実験要領およひ計測方法}

ダクトの上流 (風洞吹出口部) から $75 \mathrm{~mm}$ 離れた位置にスピーカを図1のように設置し，発信器より正弦波を 掃引させ , パワーアンプを介してスピーカを駆動する . 各マイクロホンの出力は騒音計測システムを経て FFT 分 析器に入り，トラッキング処理されて周波数に対する騒音值として求めた後パソコンに取り込んだ .

周波数範囲は $200 \mathrm{~Hz} \sim 5000 \mathrm{~Hz}$, 周波数分解能は $12.5 \mathrm{~Hz}$, 掃引時間は 500 秒 1 掃引である. 計測ブロック線図 を図 3 に示す。

実験パラメータは以下のとおりである .

（1）吸音処理 : 有り ( $\mathrm{GW}, \mathrm{t} 20\left[\right.$ 厚み $20 \mathrm{~mm}$, 嵩比重 $\left.48 \mathrm{~kg} / \mathrm{m}^{3}\right)$ と無し，ここで $\mathrm{GW}$ はグラスウールを示す .

(2) 曲がり部の個数 : 1 (1/2曲がり管)，2 (全曲がり管)

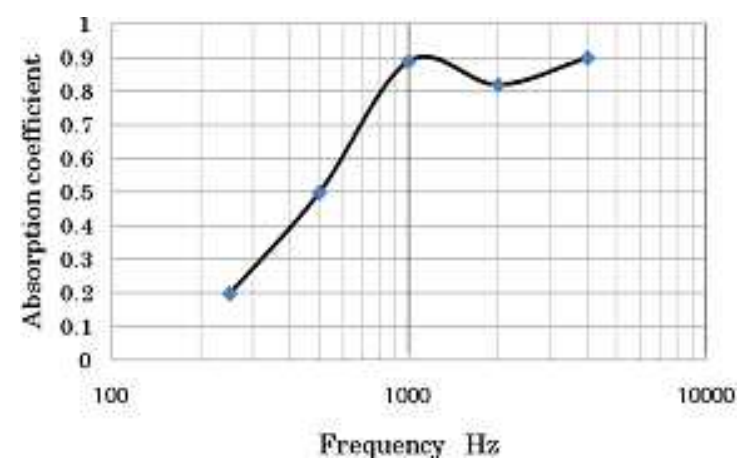

Fig.4 Absorption coefficient of GW

なお，図 4 に本実験で用いたグラスウール (厚み $20 \mathrm{~mm}$, 嵩密度 $48 \mathrm{~kg} / \mathrm{m}^{3}$ ) の吸音率の周波数特性を示す．

\section{$2 \cdot 3$ 実験結果と考察}

\section{$2 \cdot 3 \cdot 1$ 曲がり管の断面音圧分布}

曲がり管では直管に比べ断面の音圧分布が生じやすいと考えられたため，ダクト内減音量を計測するに先立ち 音源に近い位置と遠い位置の2つの断面において音圧分布を計測した . 図 5 (a)に断面内計測位置を图 5 (b)に計測 結果 (オーバーオール值) を示す.記号 $\mathrm{t} 0$ ， $\mathrm{t} 20$ は光れ光れ吸音材無し，有りを示しており， near，far は光れ光 れ音源に近い場合，遠い場合のマイク位置 (乥れ光れ原点より $0.1 \mathrm{~m}, 2.4 \mathrm{~m}$ ) を示す. 図 5 (b)より音圧の分布はほ ぼ一樣とみなせる．またこの図よりオーバーオールでの曲りダクトの低減量は $\mathrm{t} 0$ において約 $8 \mathrm{~dB}, \mathrm{t} 20$ において 約 $27 \mathrm{~dB}$ である .

(a)

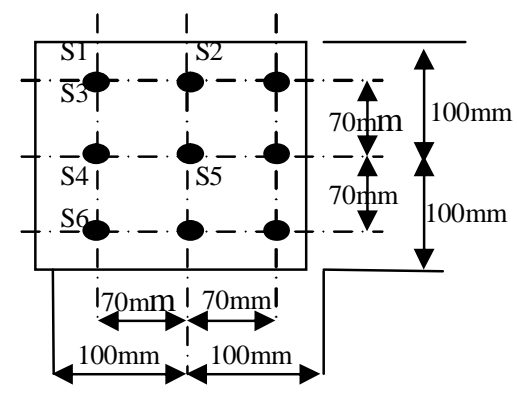

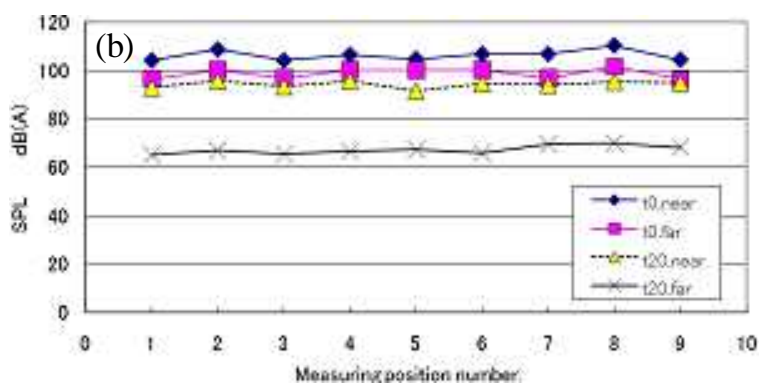

Fig5 SPL(O.A) at each position 


\section{$2 \cdot 3 \cdot 2$ 曲がり管の減音量}

図 6 (a) に全曲がり管と図 6 (b) に1/2曲がり管の各計測位置における騒音レベルの O.A.值を示す . 図中の記 号 $\mathrm{t} 0$ と $\mathrm{t} 20$ は光れ光れ吸音処理無しと，20mm の GW を用いて吸音処理した場合を示している．また，記号 ref は端部が反射端，non-ref は端部に吸音材（長さ $200 \mathrm{~mm}$ のグラスウール）を取り付けた場合である．

図 6 (a)より，端部反射の有無の騒音レベルに与える影響はほとんど無いことか摫える .これは既報(8)の直管名 クトでも得られている . また曲り部の減音量については 2 回曲がり [全曲り管 : SPL(0.6m)-SPL(1.85m)] と 1 回曲

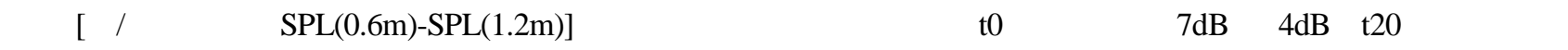
$18 \mathrm{~dB}$ と $8 \mathrm{~dB}$ である .このことから吸音の有無によらず曲がりの回数と低減量の関係はほぼ比例すると言える .

しかしながら減音量は周波数により異なる物理量であるので, 各周波数帯での減音量を示し, 曲げ回数による 変化について調べる必要がある. 図 7 と图8は关れ光れ吸音材無し, 吸音材有りについて1回曲がり, 2 回曲が りの減音量をオクターブ中心周波数に対して示したものである. 図中の凡例において $\mathrm{t} 0$ と $\mathrm{t} 20$ は光れ光れ吸音材 無し，有りを，また $1 / 2$ duct と Total duct は乥れ光れ 1 回曲がりと 2 回曲がりを表わしている . 各中心周波数にお いて1回曲がりに対する 2 回曲がりの減音量の比 (図の右側の枠内に示す) を求めると厳密には 2.0 ではないが， 10 点のデータの平均值は 2.5 であることから , 減音量は曲がりの回数にほぼ比例すると言える .

図 9 に全曲り管のオクターブバンド中心周波数における1回の曲がりによる低減量を本実験結果とダクト断面 寸法がほぼ同じである $\mathrm{D}=250 \mathrm{~mm}$ の角型エルボの文献結果 ${ }^{(7)}$ を並べて示す .ただし，文献での吸音材の厚みは $25 \mathrm{~mm}$ である.また本実験結果は全ダクト ( 2 回曲がり) について, $0.6 \mathrm{~m}$ と $2.4 \mathrm{~m}$ (端部) の騒音レベルの差の $1 / 2$ て評価したものである. 兴の理由は前述したように減音量が曲がりの回数にほぼ比例するためである .
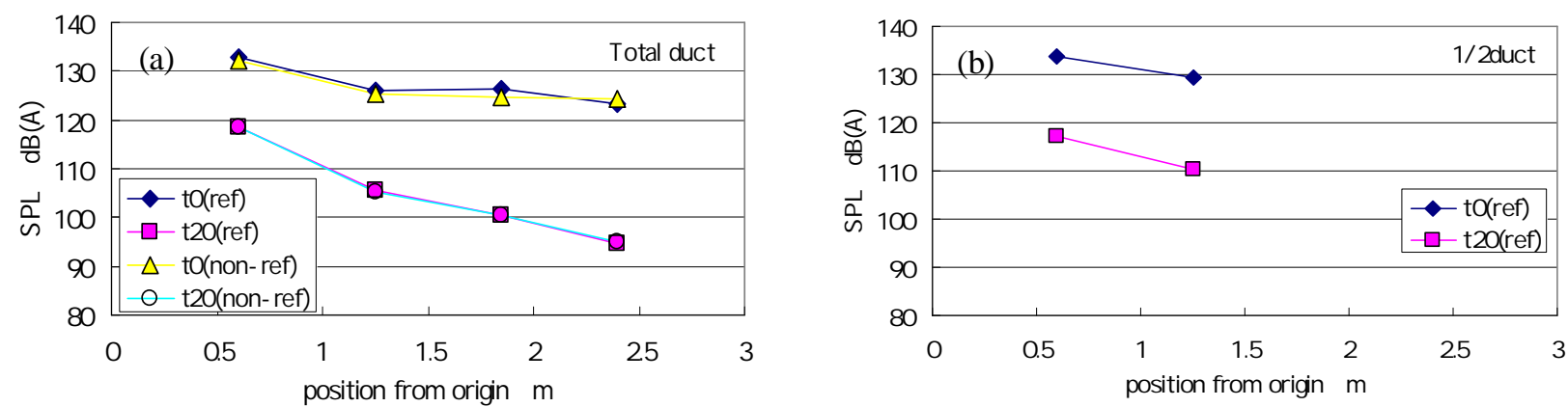

Fig.6 SPL(O.A) at each position

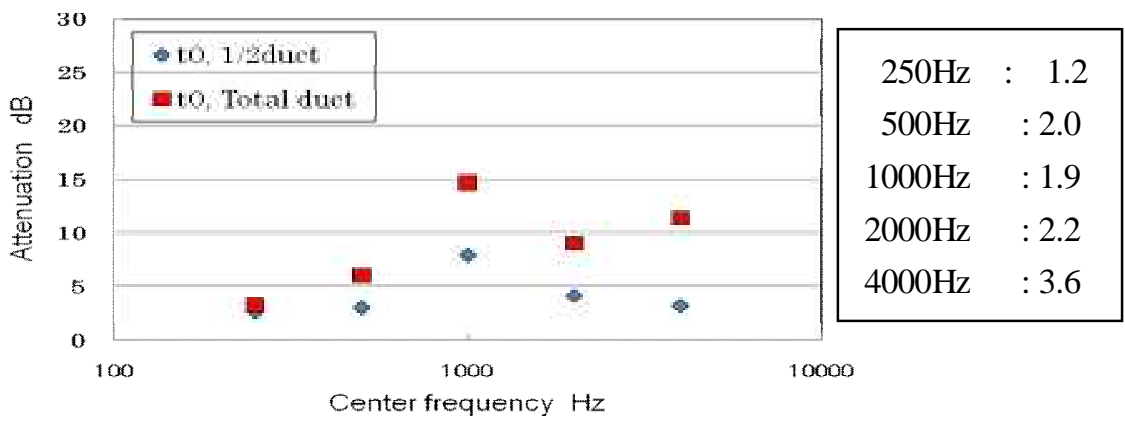

Fig.7 Attenuation (without absorbent)

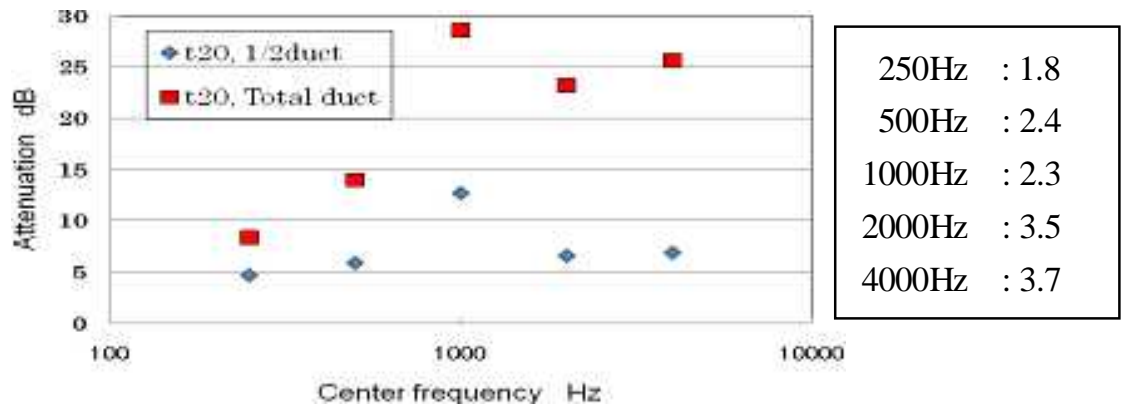

Fig.8 Attenuation (with absorbent) 


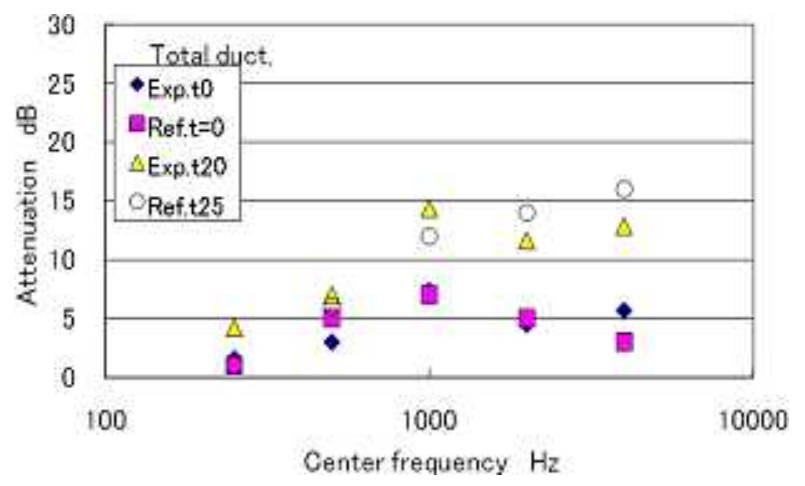

Fig.9 SPL(O.A) at each position

この図より，本実験結果と文献の結果とは t0（吸音材無し）および t20（吸音材有り）共に文献結果と比較的 よい一致を示した .このことからも曲がりダクトの減音量が曲がりの回数にほぼ比例すると言える .

\section{3. 流体音特性に関する実験 (気流有り)}

\section{1 実験装置と実験方法}

実験装置は図 1 と同じである.ただし，図1に示しているダクト内の騒音計測の代わりにダクト出口 (端部) より斜め $45^{\circ}$ 方向 $100 \mathrm{~mm}$ の位置に置いたマイクで流体音の計測を行った . ダクトの根元全圧は図 1 に示すよう にダクトの上流 (風洞吹出口部) から 100mm 下流に離れた位置に全圧管 (図 1 では Total pressure tube) を設置し，
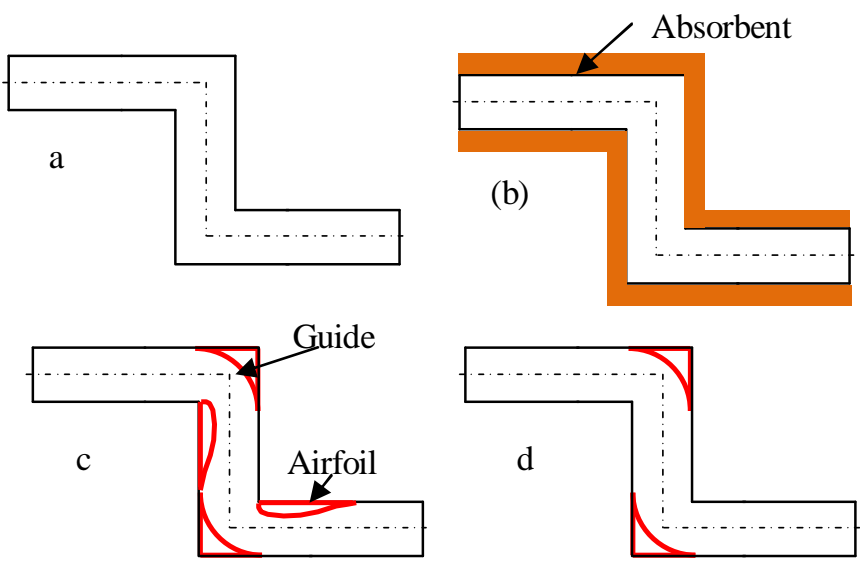

Fig.10 Kinds of duct

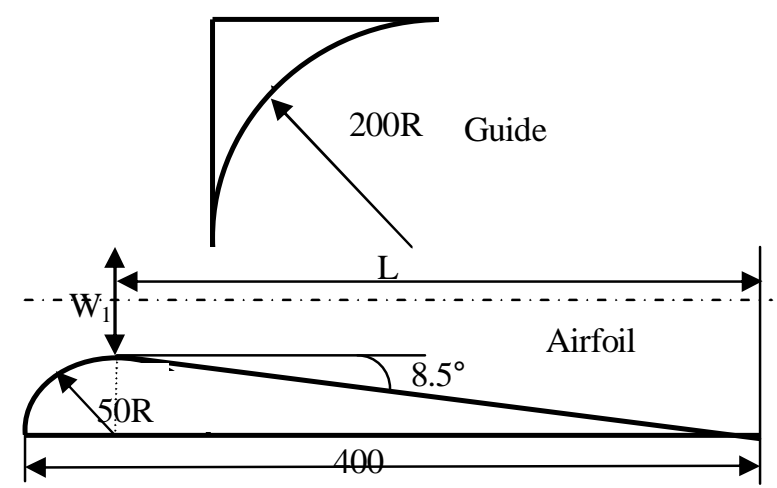

Fig.11 Detail of devices 
デジタルマノメータを見ながら下記に示す試験全圧になるようにファン回転数を調節する . 試験全圧になつた 後騒音と流速の計測を開始する . 各マイクロホンの出力は騒音計測システムを経て F F T 分析器に入り , 周波数 分析された後パソコンに取り込まれる. 周波数範囲は $200 \mathrm{~Hz} \sim 5000 \mathrm{~Hz}$ ，周波数分解能は $12.5 \mathrm{~Hz}$ である.また実 験パラメータは以下のとおりである .

(1) 試験全圧 : $50 ， 170 ， 430 ， 750 \mathrm{~Pa} ， 900 \mathrm{~Pa}$

(2) ダクトの種類 : 図 10 に示す 4 通りのダクトで, 乥れ光れ次の条件である. 図 11 にガイドと翼型の詳細を 示す。

(a) 吸音材無 , ガイドおよび翼型無

(b) 吸音材有 , ガイドおよび翼型無

(c) 吸音材無, ガイドおよび翼型有

(d) 吸音材無, ガイド有, 翼型無

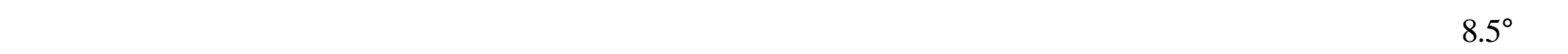
翼面を製作した。用いた式を下に示す ${ }^{(12)}$.

$$
2 \alpha=23 \times\left(L / W_{1}\right)^{-0.351} \quad\left(1<L / W_{1}<30\right)
$$

ここでL , W1 は図 11 に示した長さである .

\section{$3 \llbracket 2$ 曲り管の流体音の周波数特性}

曲り管に流れを与えた場合にダクト出口から放出される流体音の周波数特性を調べた . ダクトの根元全圧が公 称 $50 \mathrm{~Pa} ， 170 \mathrm{~Pa} ， 430 \mathrm{~Pa} ， 750 \mathrm{~Pa}$ および $900 \mathrm{~Pa}$ の 5 通りについて実験を行った . 1/2 ダクトの騒音レベルの周波数 特性の一例として 170Pa と 750Pa の場合を図 12 と図 13 に光れ示す. 図中の凡例(a)〜(d)は図 10 に示すダク トの種類を示しており，また図中の数字は上から(a) , (b) , (d) , (c)の順の騒音レベルの O.A.值を示している .な お，これ以降の図に示す凡例(a)〜(d)の見方はすべて同じである .

これらの図より低周波域において山が生じており，乥の卓越周波数か根元全圧の大きいほど高周波側に移動し ていることがわかる .このことを詳しく調べるために 4 種類のダクトと 5 種類の根元全圧のパラメータからなる 合計 20 ケースについて根元流速 U と卓越周波数 fp を求めた . 兴の数值を表 1 に示す .

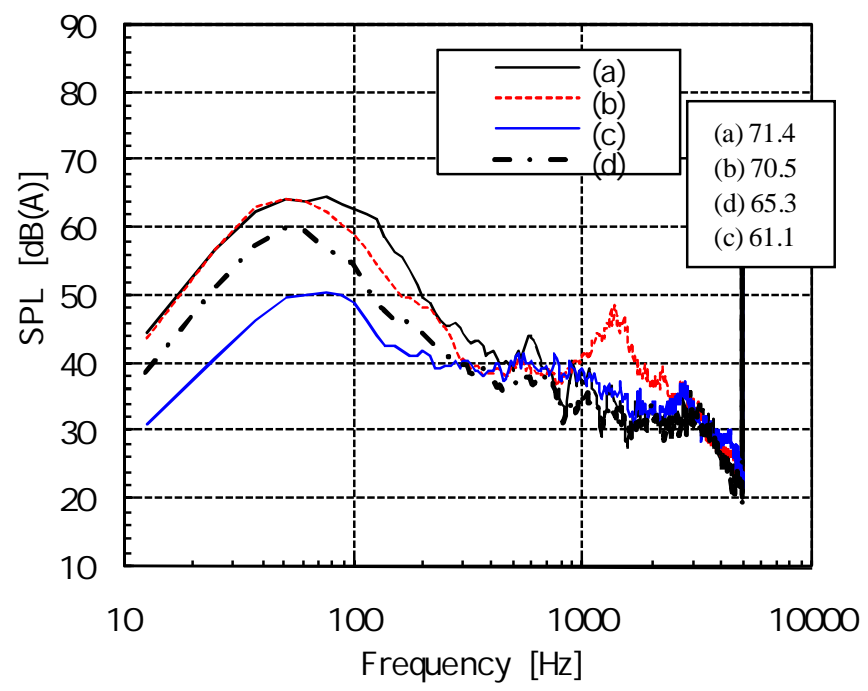

Fig.12 Spectrum of SPL $(\mathrm{Pt}=170 \mathrm{~Pa})$ 


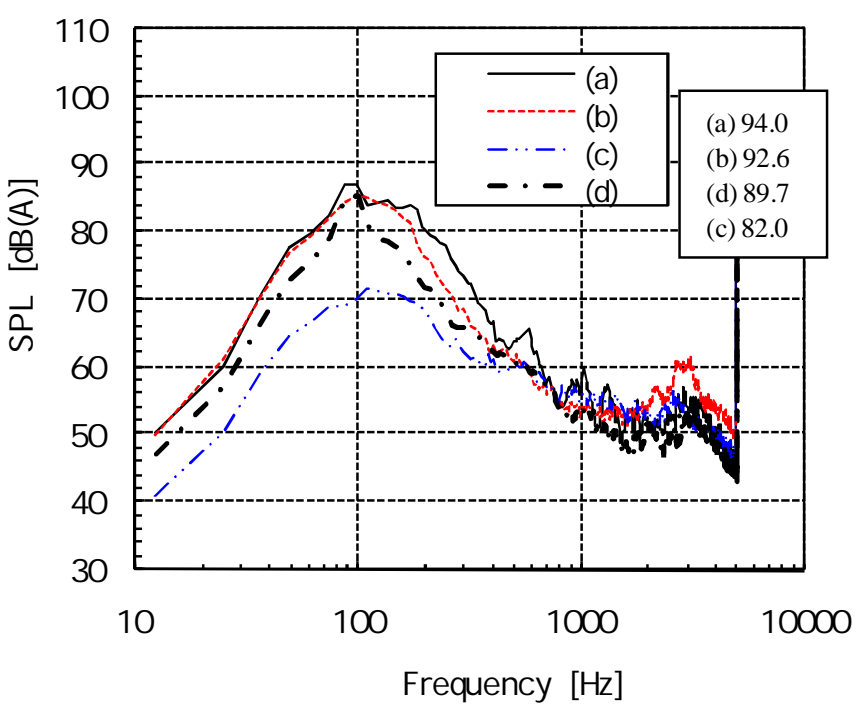

Fig.13 Spectrum of $\operatorname{SPL}(\mathrm{Pt}=750 \mathrm{~Pa})$

Table 1 Root velocity and peak frequency in four cases of $1 / 2$ duct

\begin{tabular}{|c|c|c|c|c|c|}
\hline & & (a) & (b) & (c) & (d) \\
\hline \multirow[t]{2}{*}{$\mathrm{Pt}=50 \mathrm{~Pa}$} & $U(\mathrm{~m} / \mathrm{s})$ & 4.8 & 5. 0 & 6. 3 & 4. 4 \\
\hline & $\mathrm{Fp}(\mathrm{Hz})$ & 35 & 35 & 40 & 30 \\
\hline \multirow[t]{2}{*}{$\mathrm{Pt}=170 \mathrm{~Pa}$} & $U(\mathrm{~m} / \mathrm{s})$ & 9.5 & 9.5 & 10.8 & 9.3 \\
\hline & $\mathrm{Fp}(\mathrm{Hz})$ & 65 & 55 & 68 & 55 \\
\hline \multirow[t]{2}{*}{$\mathrm{Pt}=430 \mathrm{~Pa}$} & $u(\mathrm{~m} / \mathrm{s})$ & 14. 3 & 14. 3 & 16. 5 & 14. 1 \\
\hline & $\mathrm{Fp}(\mathrm{Hz})$ & 85 & 80 & 100 & 80 \\
\hline \multirow[t]{2}{*}{$\mathrm{Pt}=750 \mathrm{~Pa}$} & $u(\mathrm{~m} / \mathrm{s})$ & 18. 5 & 18.5 & 21.7 & 18. 4 \\
\hline & $\mathrm{Fp}(\mathrm{Hz})$ & 100 & 100 & 115 & 110 \\
\hline \multirow[t]{2}{*}{$\mathrm{Pt}=900 \mathrm{~Pa}$} & $u(m / s)$ & 20. 0 & 22. 0 & 23.5 & 20. 2 \\
\hline & $\mathrm{Fp}(\mathrm{Hz})$ & 110 & 120 & 130 & 110 \\
\hline
\end{tabular}

この表から同じ根元全圧に対し，ダクト(c)のみが流速が大きくなっており，流れが他のダクトに比べ滑らかで あることか窺われる .これらの数值を，横軸に根元流速 U を縦軸に卓越周波数 fp をとり図 14 に示す . この図よ りダクトの種類によらずほぼ同じ直線となっており，弚の勾配は約 5.6 となった .これより代表寸法としてダク 卜の辺長 $\mathrm{D}(\mathrm{D}=0.2 \mathrm{~m})$ をとりストロハル数を $\mathrm{St}=\mathrm{fp} ・ \mathrm{D} / \mathrm{U}$ として求めると, $\mathrm{St}=1.12$ となった . この無次元数が 全ダクトについても同じになるかを同樣の方法で求めたところ図 15 のようになった .

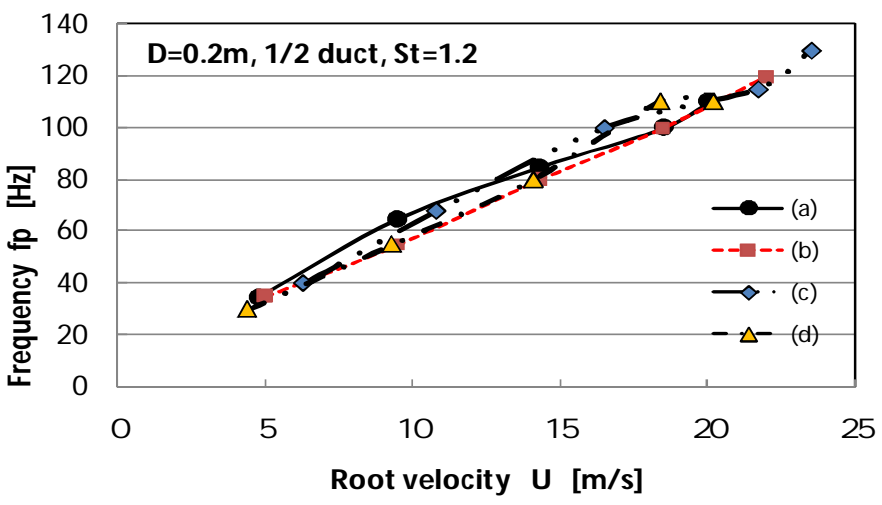

Fig.14 Relation between fp and U (1/2 duct) 


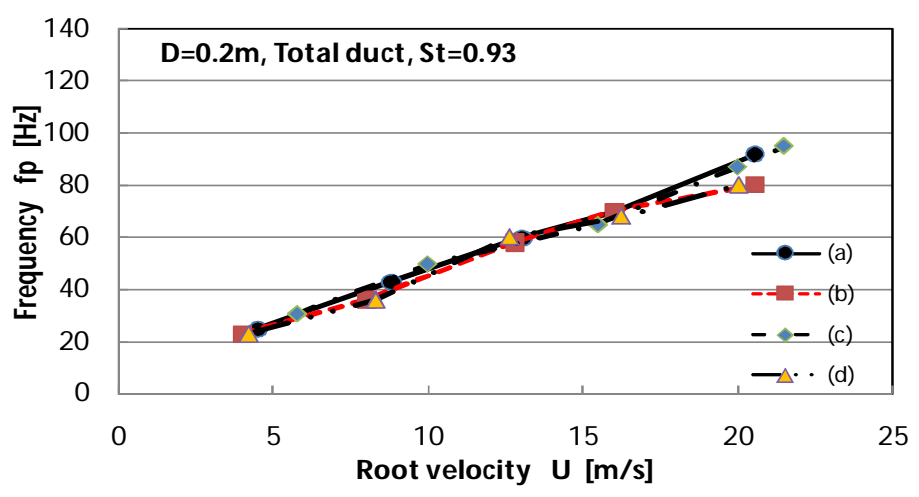

Fig.15 Relation between fp and $U$ (Total duct)

この結果より全ダクトでもダクトの種類によらずほぼ同じ直線になることは同じであるものの，ストロハル数 自身は $\mathrm{St}=0.93$ となり必ずしも $1 / 2$ ダクトの光れとは一致しないことがわかった . 両図の違いは曲りの回数であ り，この実験からでは曲りの回数が少ない方がストロハル数の值が大きくなるようである．しかしながら曲がり 回数のストロハル数に及ぼす影響は大きさが異なる数種類の実験を行う必要があるので今後の課題としたい．

\section{$3 \square 3$ 曲がり管の流れによる騒音増加量と录離防止デバイスの効果}

図 16 および図 17 に光れ全曲り管と $1 / 2$ 曲り管についての流れを与えた場合の根元流速と出口騒音レベル の実験結果を示す.図中には図 10 に示す概略図 (a) 吸音無し，(b) 吸音有り，(c) 吸音無しかつガイド+翼型， (d) 吸音無しかつガイドのみ, の 4 種類のデータを示す . 図中の(a), (b) , (c) , (d)の記号は上記凡例に対応して いる．また図 18 は条件(c)のダクト内の写真である.

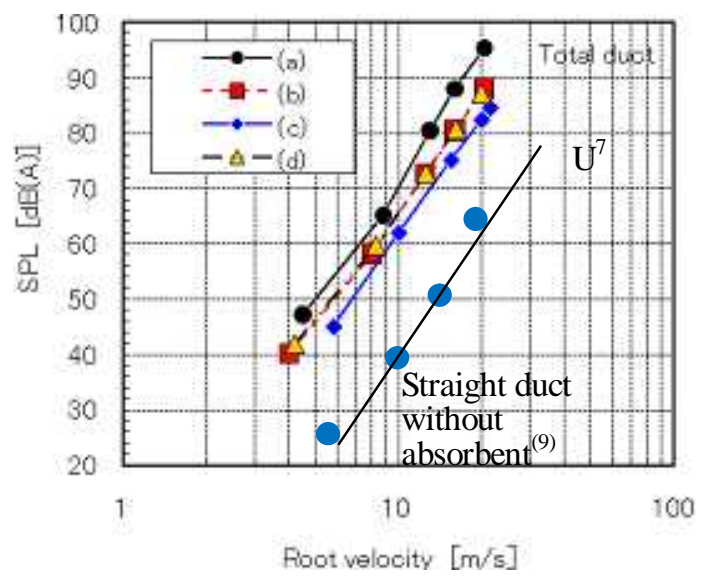

Fig.16 SPL(O.A) for four ducts(Total duct)

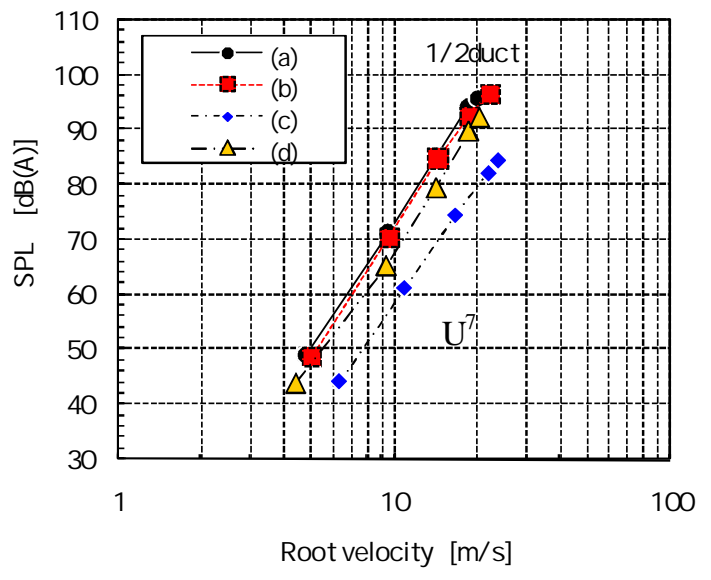

Fig.17 SPL(O.A) for four ducts(1/2 duct) 


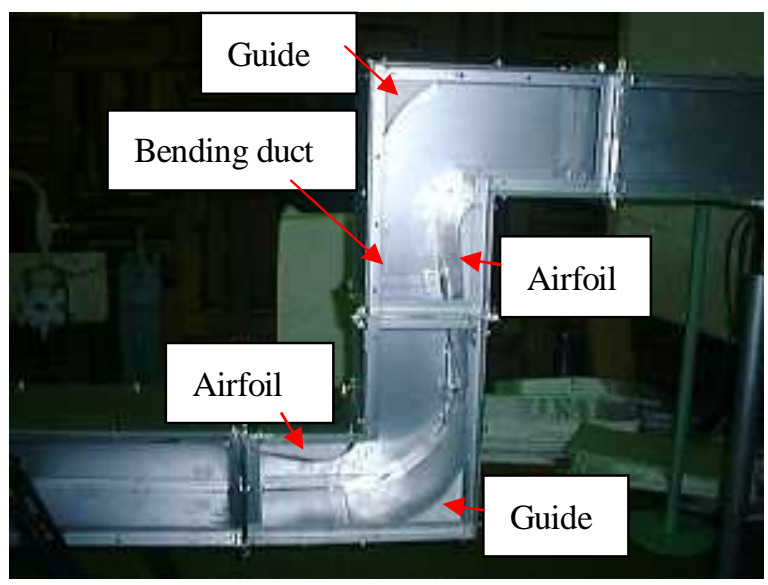

Fig.18 SPL(O.A) at each position

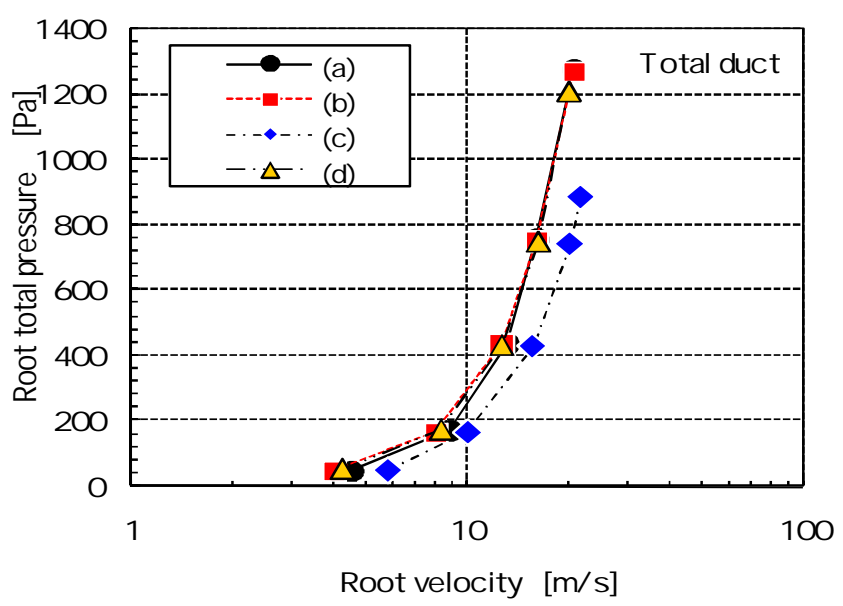

Fig. 19 Relation between Pt and U

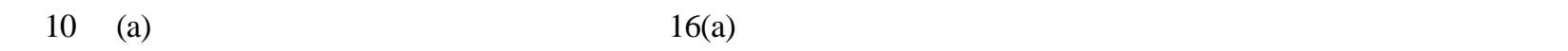
ての騒音レベル (図中の青い丸い印) ${ }^{(9)}$ を比較すると，直管と曲り管ダクトの騒音レベル差は約 $30 \mathrm{~dB}$ 曲り管が 大きい. 具体的に弚の差を示すと $4.5 \mathrm{~m} / \mathrm{s}: 28 \mathrm{~dB} ， 8.8 \mathrm{~m} / \mathrm{s}: 29 \mathrm{~dB}, 13 \mathrm{~m} / \mathrm{s}: 30 \mathrm{~dB}, 16 \mathrm{~m} / \mathrm{s}: 31 \mathrm{~dB}$ である.このこと から曲り部て录離することによって発生する音は非常に大きいと言える .

図 16 と図 17 の光れ光れについてダクト条件(a)と(b)を比較すると吸音材の効果は全曲り管て約 $5 \mathrm{~dB}, 1 / 2$ 曲り 管て約 $1 \mathrm{~dB}$ である.流れがある場合の吸音材効果は音響試験での曲り吸音効果 (全曲り管：18dB，1/2曲り管： $8 \mathrm{~dB})$ ほどには減音効果力得られない．これは音響試験での音源は上流側の一点に存在しているのに対し，流れ がある場合の音源は管軸に沿って音源か発生するためであることと流体音の卓越周波数が $100 \mathrm{~Hz}$ 前後であるため， グラスウールの吸音率か極めて小さいため等であると考えられる．しかしながら本実験に用いたダクトや吸音材 は通常使用される大きさや厚みであるため，本実験結果は普遍性はないものの有用であると考える .したがって， 音響試験での吸音材の減音効果を流れによって発生する音に適用することは問題がある．

図 16 と図 17 において(a)と(c)の騒音レベルを比較するとガイド+翼型の効果は全曲り管て約 $10 \mathrm{~dB}, 1 / 2$ 曲り管 て約 15dB である .一方，吸音材の効果を示す(a)と(b)の差は上述のように全曲り管て約 $5 \mathrm{~dB}, 1 / 2$ 曲り管て約 $1 \mathrm{~dB}$ とわずかである .すなわち流体騒音の低減には吸音材よりガイド+翼型の方か洨果的であると言える .

図 19 に根元流速と根元全圧の関係を示しているが ,デバイス (ガイド+翼型) をつけると最大流速時の全圧が 約 $2 / 3$ に減少していることがわかる.このことから圧損を減らすことか騒音低減に繋がると推測される．しかし ながら(a)と(d)の比較では図 19 より全圧損失に差が見られないのに, 図 16 では騒音レベルが咸少しており, 騒音 低減の原因が全圧損失のみではないと考えられる．すなわちガイドは全圧損失の減少には寄与しないか騒音レベ 
ルの減少には寄与している .これはガイドがなくてもガイド部か死水領域となり，あたかもガイドがあるのと同 じ状態となるため圧力損失が咸少しなかったためである。

(c)において翼型を無くした(d)を見ると，全曲り管て約 $3 \mathrm{~dB} ， 1 / 2$ 曲り管て約 $10 \mathrm{~dB}$ 悪くなる．したがって翼型 は騒音を防止するのに有用である .

また , 本実験では曲り管の流速依存性はすべての条件で 7 乗則であつた .これは既報 ${ }^{(8)} の$ 直管の場合と同樣で あり，さらに文献（７）では「角型エルボの場合発生音は流速の７乗に比例する」とあるので本実験での流速依 存性は妥当と思われる.

\section{4. 結 言}

曲り管ダクトの音響特性および流体音特性を実験的に検討した . その結果以下の知見が得られた .

(1) 曲り管の音響減音効果は文献の值とほぼ同じであり, 曲り管が 2 段の場合の減音効果はおおまかには 1 段の光れを 2 倍して評価できる .

( 2 ) 流れがある場合の曲り部による騒音レベルのアップ量は約 $30 \mathrm{~dB}$ B であり，光の原因は曲がり部における 複杂倠な流れ，例えば录離や渦の運動であると思われる．

( 3 ) 正方形断面の曲りダクトから発生する流体音の卓越周波数はダクト内の吸音材の有無や录樆倠方止デバイ スの有無には関係なく，流速に比例し，代表寸法に反比例する. 光の係数であるストロハル数は代表寸 法を辺長 D とすれば，本実験では一回曲りの場合で約 $1.12,2$ 回曲りの場合て約 0.93 であった .しかし 現段階ではこれらの值に普遍性はない .

( 4 ) 录樆倠方止デバイスは約 10dB 以上の低減効果がある. 特に翼型の効果か汥配的である.

（５）通常使用されるダクトでは，流れによって生ずる音の卓越周波数が $100 \mathrm{~Hz}$ あたりにあるため，吸音材の 効果が表れにくく，本実験では流れによって生ずる音に対する吸音材の低減効果は平均して $3 \mathrm{~dB}$ 程度で あり，音響的な゙減音量 (約 $25 \mathrm{~dB})$ に比較してわずかである．したがって，流れがある場合（ただし，流 れのみが音源である場合に限る）の吸音材の効果を音響的な关れて評価することは極めて危険である．

\section{文献}

（1）渡辺要, 勝田高司, 石井聖光, 後藤滋, 寺沢達二, 板本守正, 送風時におけるダクト系統の発生騒音に関する研究, 空気調和・衛生工学, 第 37 巻, 第 5 号, $1963, p p .354-365$

(2) 塩川博義, 板本守正, グラス・ファイバ・ダクト直管部の音響特性について, 日本建築学会計画系論文報告集, 第 453 号 , 993 , pp.9-15

(3) 板本守正, 塩川博義, グラス・ファイバ・ダクト直管部の気流による発生騒音につい, 日本建築学会計画系論文 報告集 , 第 428 号 , 1991，pp.21-27

（4）板本守正, 塩川博義, 近藤一成, 白沢達哉, 武田浩之, 西村寛, グラス・ファイバ・ダクト直管部および曲管部の 気流および音響特性について，日本騒音制御工学会技術発表講演論文集，1989，pp.213-216

（5）板本守正, 塩川博義, 近藤一成, 白沢達哉, 武田浩之, 西村寛, グラス・ファイバ・ダクト分岐部の気流および音 響特性について, 日本騒音制御工学会技術発表講演論文集, 1989, pp.209-212

（6）板本守正，塩川博義，武田浩之，西村寛，内張りダク卜直管部および曲管部の気流および音響特性に関する研究， 日本建築学会大会学術講演梗概集, 1990, pp.459-460

(7) 日本騒音制御工学会編，建築設備の騒音対策1ダクト系の騒音対策，技報堂出版，1999，p.40

（8）石原国彦, 開口部を有する直管ダクトの音響特性に関する研究, 機械学会論文集 (C 編)，74 巻, 738 号, 2008 , pp.332-338

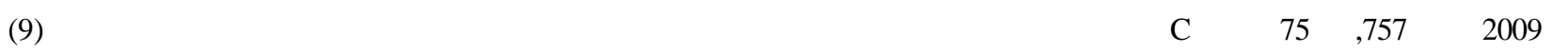
pp.2521-2528

(10) 白木万博監修, 騒音防止設計とシミュレーション，応用技術出版，1987，p.217

(11) Leo L. Beranek, Noise and Vibrastion Control, McGraw-Hill, 1971 ， p.384

（12）望月修，丸田芳幸，流体音工学入門一豊かな音環境を求めて一，朝倉書店，1996， p.64 